\title{
パインコーン型ヨット保管構造物の構想と設計
}

\author{
東海大学 海洋学部 学生員 仲倉 道雄 \\ 東海大学 海洋学部 正会員 長崎 作治 \\ 和田辺製作所正会員 石川 和男
}

1.はじめに

我が国でも、週休 2 日制の普及、長期夏季休㗇、有給休暇の増加、ゴールデンウィークなどによる連続休睱の 増加、労働時間の短縮による余暇時間の増大など自由時間増大の方向が示されつつあり、余艰やレクリエーショ ンに生活の重点を置く国民が增加している。昭和63年11月、日本海事広報協会発行“海洋レクリエーションの現 状と展望”によると、余层の過ごし方は、従来の観光地めぐりや温泉地における休養などの観光型のものから、 スキー、モーターボート、ヨットなどのスポーッや森林浴、野鳥観察などによる自然との触れ合いを重視するな どの、余暇の目的を明確にした創造的な過ごし方が徐々に定着しつつあると述べている。そして、近年貿易摩擦 回避のための内需拡大策と、リソート法の成立により、地域活性化を目指したリソート開発構想がいま全国各地 でさかんである。そして我が国のマリーンスポーッも、大きな流れとなって国民一般のレジャー活動に定着しよ うとしている。モーターボート、ヨットの保有隻数の推移は図-1のように、昭和 45 年に 8 万隻であったものが 62 年には 25 万隻になっている。海外での普及を 1 隻当たりの人口で比較すると、図-2に示すように北欧三国 が著しいほか、イギリス、フランス、西ドイッはそれぞれ65人、93人、138人と我が国の5 54 人に対し て4〜8倍の普及ぶりである。そして今後その需要は欧米諸国の水準に近づいていくことが予想される。こうし た背景の中でマリンレジャーの受皿であるマリーナ開発への関心も大きな高まりを見せ、全国各地で公共、民間 双方による開発構想が提出、あるいは検討されている。その内容としてレジャーブームの盛り上がりを受けて、 マリーナを核にショッピング施設やホテル、商業地区など都市機能を備えたウォーターフロント都市に衣替えし ようとしてきている。

\section{2. 現在の状況と問題}

通常、マリーナの建設には防波堤、埋立、道路といっ た基盤整備に巨額の投資を必要とする。ところが、我が 国のマリーナの $90 \%$ 以上を占める民間マリーナは、国 の助成措置から見離されている。したがって一部を除い て民間マリーナは小規模であり保管料金が高く、設備も 不満足なものにならさるを得ない。一方、公共マリーナ に対しては、料金は安いが、サーヒススは部を除き乏し いしいという現状が上げられる。すでに満足の行くサー ビスを持っているのは超八イクラスのマリーナのみであ る。そして、問題点は民間、公共とも海域利用である。 これまで、マリーナは入江や河川など波が静かで、防波 堤を必要としない場所につくられてきた。ところが、こ れら静稻でマリーナに適した海域は、昔から漁業活動に よって占有されており、海面利用の調整が困難で、漁業 保証と引き換えに得られる利用水域も決して広くない。 現状としてはマリーナとプレジャーボートは、漁業と共 存しにくい環境にあり、本来、国民の共有であるべき水 面を自由に使えない現状である。こんな厳しい背景が、 ヨット・ボートの放置艇の增加につながっているという 見方がある。

運輸省では放置艇について「全国で約 11 万隻が港湾、 海岸、河川などに放置されたままとなっており、これに よる沈船、廃船も目立ち、漁業者とのトラブルが各地で 見受けられる」と指摘、さらに「現状の放置艇数からみ

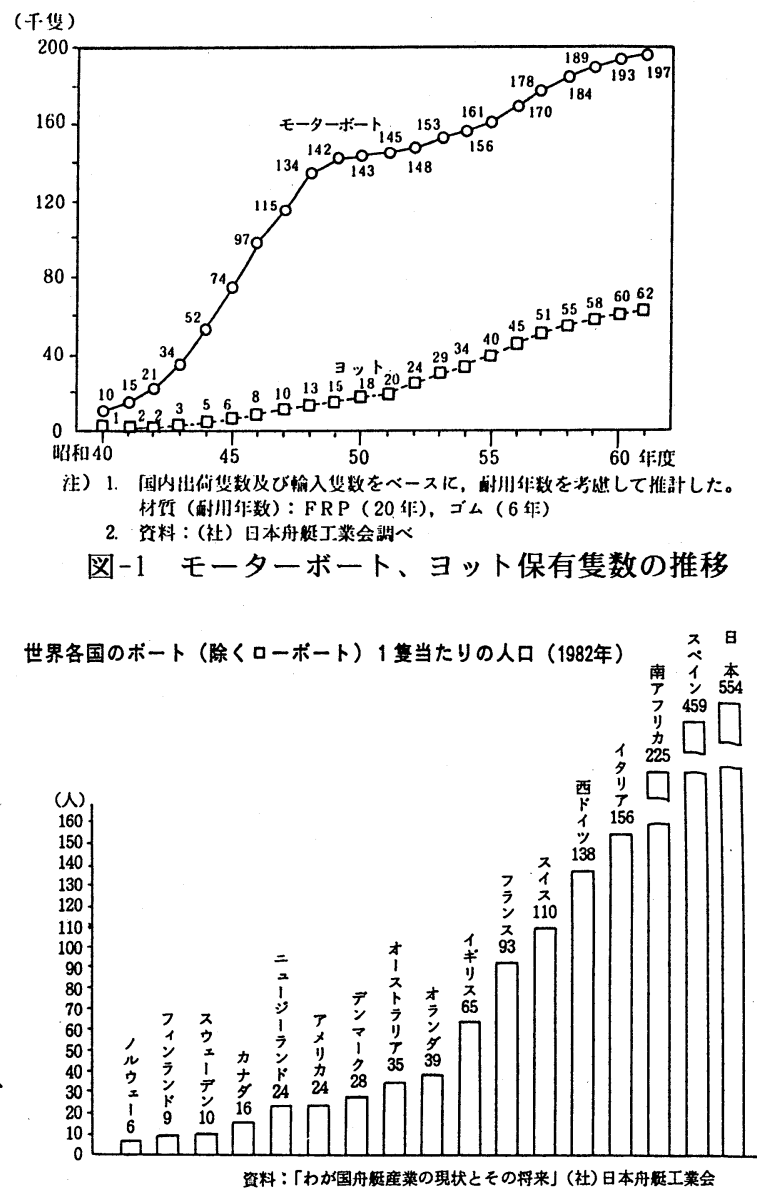

図-2 世界各国のボートの普及状況 
て、平成 10 年までに保有船数がトレンド・ベースで 3

7. 5 万隻なら放置艇は 22 万隻となる」と計算してい る。これを全部収容するとして単純計算で、収容規模 1 000 隻のマリーナなら $200 、 500$ 隻規模なら40 0 の新規マリーナが必要となり、早急に公共マリーナを 中心としたマリーナ整備を必要としている。そこで我々 は、海域高度利用構想としてパインコーン型ヨット保管 構造物を考案したので以下に紹介する。

\section{3. パインコーン型ヨット保管構造物}

\section{1 構造}

図-3 (1) に示すように、地盤に立設する支柱を中心と し、保管するヨットの全高の半分程度突出長さが短い円 形の雊段状をなす複数段のヨット保管載置段を設けた構 造と、図-3(2) のように各載置段間の高さをヨットのマ ストよりも十分に低くし、最下段を除く各載置段のヨッ ト収納スペースの間にその下位の載置したヨットのマス トが挿通する切り込みが放射方向に設けた 2 構造がある。 両方とも最下段部には、ヨット接舷部を設け、干満に応 じて乗員が上陸できる浮栈橋をもつ。ヨットはヨット収 納スペースと海面との間を、円柱上部に設けた水平移動 クレーンで吊揚げ、吊降ろし移送できる。これが、パイ ンコーン型ヨット保管構造物であり、従来のように海面 に平面的に保管するのに比べ、立体的に保管するので生 物付着防止ができ、しかも多くの隻数を保管することが 可能となる。またこの構造物は、ヨットを対象としたも のだが、各載置段のヨット収容位置の内側の空間にマス 卜を持たない船艇の収容場所とすることができる。この 場合は支柱の周囲を回転するターンテーブルに船艇を設 置することにより、出し入れを特定の場所で行なえるよ うになる。

\section{2 寸法、保管隻数}

図-3(1) の場合、2 段の載置段で直径 $5 \mathrm{~m}$ の中心支柱 に海面上 $5 \mathrm{~m}$ 位置に外径 $55 \mathrm{~m}$ の 1 段目スラブ、2 段目 をその $6 \mathrm{~m}$ 上に外径 $32 \mathrm{~m}$ を設けると、長さ $10.5 \mathrm{~m}$ ・幅 $3.5 \mathrm{~m}$ ・高さ $5 \mathrm{~m}$ ・吃水深 $1.6 \mathrm{~m}$ ・マスト高 $15 \mathrm{~m}$ のヨッ 卜を隙間なく載置すると、1 段目に最大 34 隻、2 段目 に最大 14 隻、合計 48 隻を保管できる。

また図-3(2) のように載置段を 4 段持つとすると、上 記と同じ条件で 1 段目の円形スラブを海面上 $5 \mathrm{~m}$ の位置 に半径方向に長さ $27.5 \mathrm{~m}$ を設け、 2 段目のスラブを 1 段目の $6 \mathrm{~m}$ 上に半径方向に $22 \mathrm{~m}$ とし、3段目のスラ ブをその $6 \mathrm{~m}$ 上に半径方向に $16.5 \mathrm{~m}$ とし、さらに 4 段目のスラブをその $6 \mathrm{~m}$ 上に半径方向に $11 \mathrm{~m}$ の規模と した場合、これら載置段に前述のヨットを隙間なく載置 すると、1 段目 24 隻、2 段目 16 隻、3 段目 8 隻、4 段目 8 隻、合計 56 隻程度保管することが出来る。

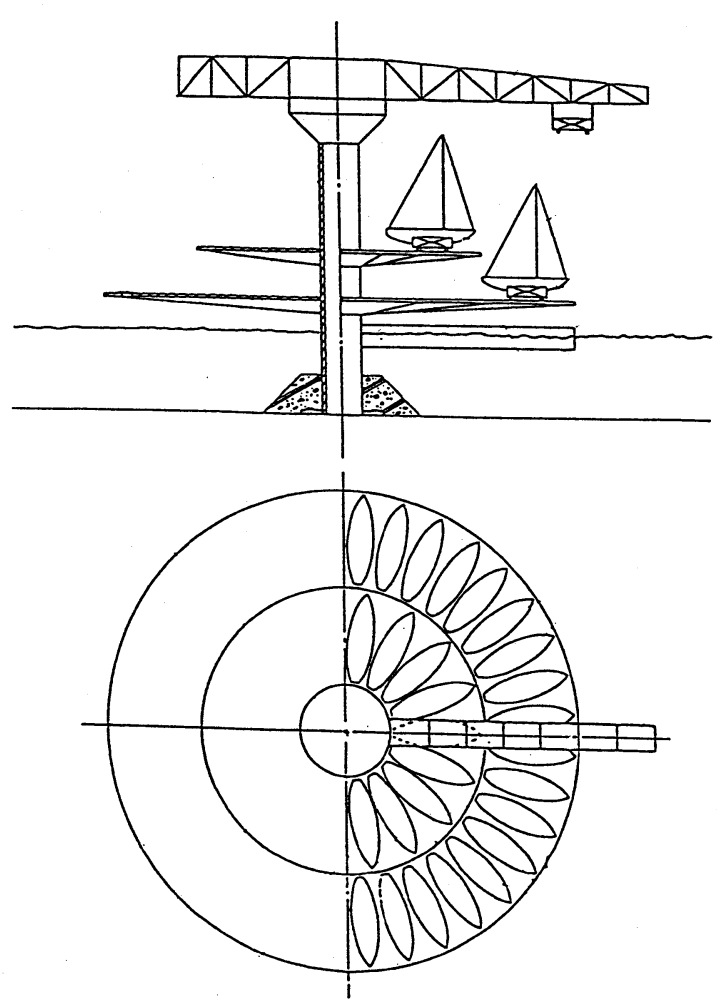

図-3(1) パインコーン型ヨット保管構造物 (雔段状)
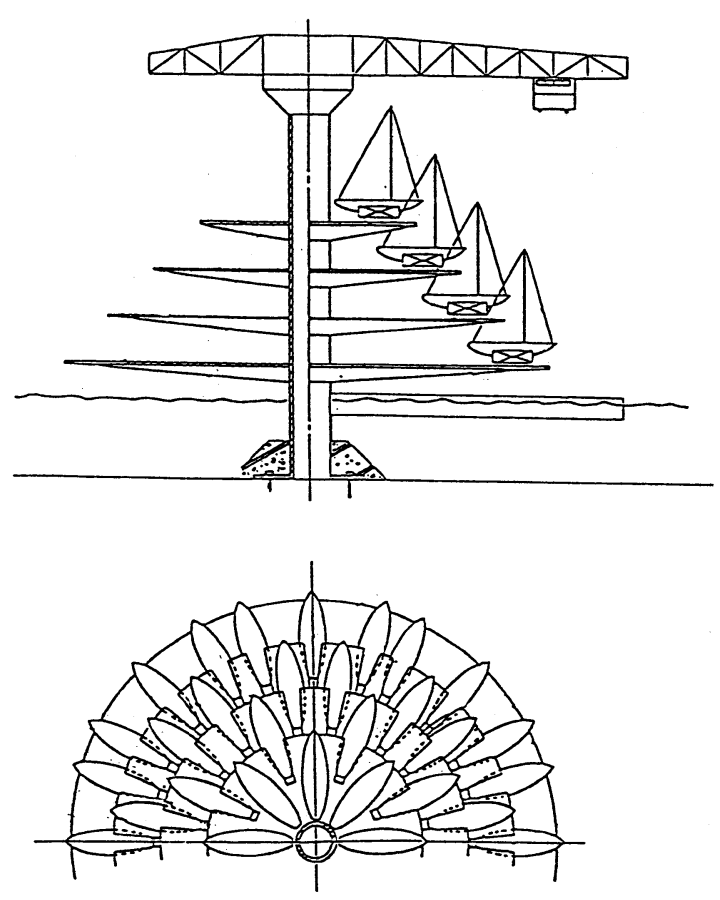

図-3 (2) パインコーン型ヨット保管構造物 （切込み、節歯状） 


\section{3 将来構想}

図-3（3）のようにパインコーン型ヨット保管構造物を 複数個間隔を置いて近接配置し、この保管構造物間を結 ぶ付帯構造物を架設した場合、この付帯構造物は、ホテ ル、レストラン、展望台、渡り廊下、あるいは潜水訓練 用の施設としても利用できる。またこの保管構造物と、 付帯構造物で囲まれた区域では網などを利用し、魚礁や ダイバーの訓練域として利用することが可能である。以 上のように、この構造物は総合リゾートマリーナとして の役目を果たせる。

4. 設計例

・設置場所 O県O市O O 海岸沖

- 設置水深 $\quad h=8.7 \mathrm{~m}+$ 潮位 $2.0 \mathrm{~m}=10.7 \mathrm{~m}$

・地盤 砂質泥岩

・設計波浪
a 沖波波高 $\mathrm{H}_{\mathrm{o}}=7.2 \mathrm{~m}$
$\mathrm{b}$ 沖波周期 $\mathrm{T}_{\mathrm{o}}=14 \mathrm{sec}$

・下向き荷重

$\begin{array}{llll}\text { a } & \text { ヨット、ボート } & 69 \text { 隻 } & 824.0 \mathrm{t} \\ \mathrm{b} & \text { クレーン重量 } & & 175.0 \mathrm{t} \\ \mathrm{c} & \text { 船台重量 } & 69 \text { 隻分 } & 20.7 \mathrm{t}\end{array}$

・パインコーン構造体寸法

$\begin{array}{llll}\mathrm{a} & \text { 脚柱 } & \text { 直径 } \mathrm{D}=5 \mathrm{~m}, \text { 肉厚 } \mathrm{t}=60 \sim 16 \mathrm{~mm} \\ \mathrm{~b} & 1 \text { 段目スラブ } & \text { 地盤上高さ } 16 \mathrm{~m} \text {, 直径 } 55 \mathrm{~m} \\ \mathrm{c} & 2 \text { 段目スラブ } & \text { 地盤上高さ } 22 \mathrm{~m} \text {, 直径 } 32 \mathrm{~m} \\ \mathrm{~d} & \text { クレーン下端 } & \text { 地盤上高さ } 42 \mathrm{~m} \text {, 直径 } 10 \mathrm{~m}\end{array}$

\section{5. 水槽実験}

我が国は台風の常竡地帯であるために、暴風、高潮、 津波、風浪、地震等自然外力が来襲する厳しい環境にさ らされている。そのため本構造物の設計にあたり波力、 風力、地震力が大きな問題となる。今回は波力に重点を 置き水槽実験を行なった。実験では円柱の直径 $\mathrm{D}=9 \mathrm{~cm}$ を用いたので、縮尺を $1 / 56$ として、2 次元水槽 $(38 \mathrm{~m} \times 1 \mathrm{~m} \times 0.6 \mathrm{~m})$ により、まず表-1に示す条件により 海底こう配０の状態についての作用波力、そして次に同 一波浪条件で 1：300海底こう配をもうけ砕波点での 作用波力を測定し、Morison, $0^{\circ}$ Brien の円形柱体波圧理 論による C D. C M 值の検討を行なった。

\section{1 海底こう配 0（非砕波）}

本構造物の脚柱直径 $\mathrm{D}$ は、 $5 \mathrm{~m}$ 程度であるので単位高 さ $\mathrm{d} \mathrm{z}$ に作用する波力 $\mathrm{d} F$ は、Morison らによって提案 された式（1．1）を用いることにした。

$$
d F=\frac{w_{0}}{2 g} C_{D} D u^{2} d z+\frac{w_{0}}{g} C_{M} \frac{\pi D^{2}}{4} \frac{\partial u}{\partial t} d z
$$
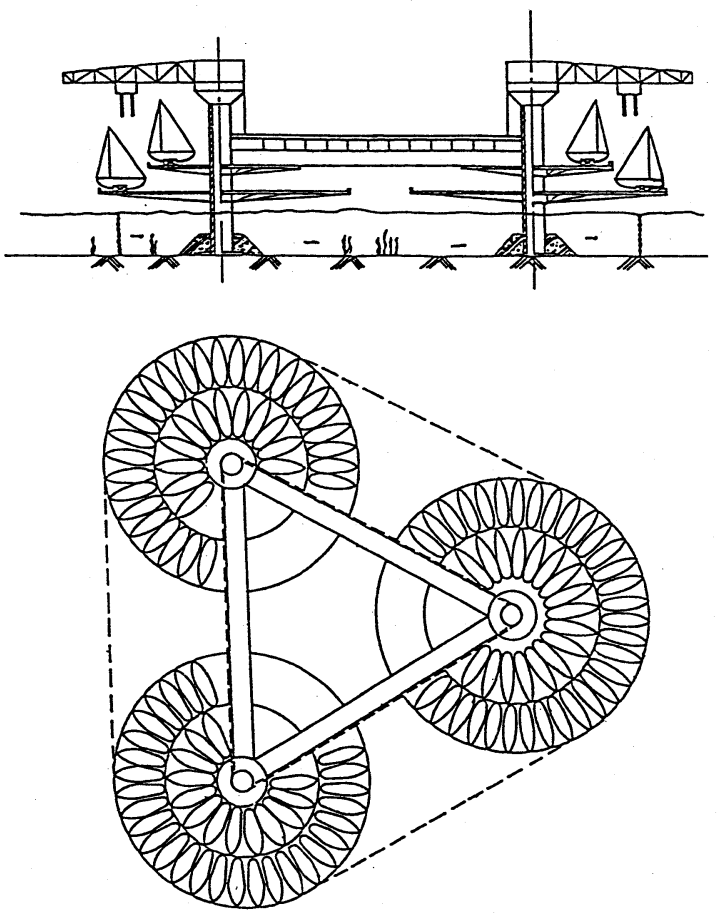

図-3 (3) パインコーン型ヨット保管構造物 （複数体）

表-1 実験波浪条件（䈹尺1/56）

\begin{tabular}{|c|c|c|c|c|c|}
\hline & & & & & \\
\hline $\begin{array}{l}\text { 水深 } \\
\mathrm{h}(\mathrm{m})\end{array}$ & $\begin{array}{l}\text { 波高 } \\
\mathrm{H}(\mathrm{m})\end{array}$ & $\begin{array}{c}\text { 周期 } \\
\mathrm{T} \text { (sec) }\end{array}$ & $\begin{array}{l}\text { 水深 } \\
\mathrm{h}(\mathrm{cm})\end{array}$ & $\begin{array}{l}\text { 波高 } \\
\mathrm{H}(\mathrm{cm})\end{array}$ & $\begin{array}{c}\text { 周期 } \\
\mathrm{T} \text { (sec) }\end{array}$ \\
\hline \multirow{12}{*}{20} & \multirow{6}{*}{ 7. 2} & 7. 5 & \multirow{12}{*}{36} & \multirow{6}{*}{13} & 1. 0 \\
\hline & & 9. 0 & & & 1. 2 \\
\hline & & 10.5 & & & 1. 4 \\
\hline & & 12.0 & & & 1. 6 \\
\hline & & 13.5 & & & 1. 8 \\
\hline & & 15.0 & & & 2. 0 \\
\hline & \multirow{6}{*}{ 5. 0} & 7. 5 & & \multirow{6}{*}{9} & 1. 0 \\
\hline & & 9.0 & & & 1. 2 \\
\hline & & 10.5 & & & 1. 4 \\
\hline & & 12.0 & & & 1. 6 \\
\hline & & 13.5 & & & 1. 8 \\
\hline & & 15.0 & & & 2. 0 \\
\hline
\end{tabular}

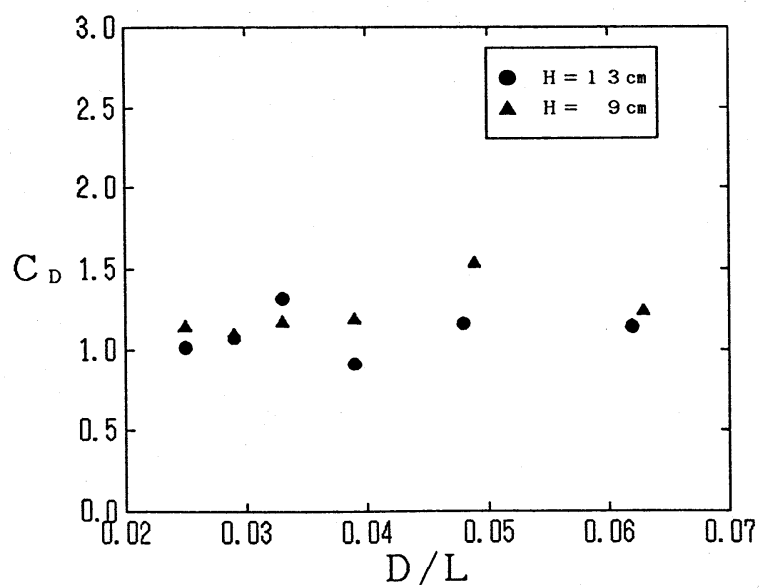

図-4（1） D/L と $C_{D}$ の関係（海底こう配 0 ） 
$\mathrm{u}=\frac{\pi \mathrm{H}}{\mathrm{T}} \frac{\cosh k(\mathrm{~h}+\mathrm{z})}{\sinh k \mathrm{~h}} \cos (k \mathrm{x}-\omega \mathrm{t})$

$\frac{\partial \mathrm{u}}{\partial \mathrm{t}}=\mathrm{a} \omega^{2} \frac{\cosh \{k(\mathrm{z}+\mathrm{h})\}}{\sinh k \mathrm{~h}} \sin (k \mathrm{x}-\omega \mathrm{t})$

d F : 部材の単位長さ当たりの波力

$\mathrm{h}$ : 設置水深

$\mathrm{w}_{\mathrm{o}}$ : 海水の単位体積重量

$C_{\mathrm{D}}$ : 抗力係数

$\mathrm{C}_{M}$ : 質量係数

a : 振幅

$k=2 \pi / \mathrm{L}:$ 波数

$\omega=2 \pi / \mathrm{T}:$ 角振動数

式（1．1）より、抗力 $\mathrm{F}_{\mathrm{D}}$ は波頂が円柱に作用した 時に最大となり、そのとき質量力 $\mathrm{F}$ ＝＝になるので、 波頂が円柱に作用したときの波力を測定すれば $\mathrm{F}_{\mathrm{D}}$ が求 まり、同時にそのときの水粒子の水平速度 $u よ り$ 抗力係 数 $\mathrm{C}_{\mathrm{D}}$ を求めることができる。また質量力 $\mathrm{F}$ M は波形が 円柱の場所で静水面にあるとき最大になり、そのとき $\mathrm{F}_{\mathrm{D}}$ =0になるからそのときの波力を測定し、同様に加速度 $\partial \mathrm{u} / \partial \mathrm{t}$ より質量係数 $\mathrm{C} 、$ が求まる。直径 $\mathrm{D}$ と波長 $\mathrm{L}$ の比 $\mathrm{D} / \mathrm{L}$ と $\mathrm{C}_{\mathrm{D}} \cdot \mathrm{C}_{M}$ の結果は図 $-4(1)$ と図-4(2) に示 すとおりである。

5.2 海底こう配 1:30（砕波）

構造物が最悪条件の砕波を受けたと仮定し実験を行な つた。砕波地点における波の運動は振動と解すべきでは なく、波の峰よりその海底面に至る各水粒子の流れとみ、 その運動速度は孤立波理論の砕波限界における水粒子速 度分布を用いた。そして加速度については、非常に小さ いので無視する。よって砕波点における作用波力は次式 で求められる。

$$
\mathrm{d} F=\frac{w_{0}}{2 \mathrm{~g}} \mathrm{C}_{\mathrm{D}} \quad \mathrm{D} \mathrm{u}^{2} \mathrm{dz}
$$

なお砕波水深 $\mathrm{h}$ 。、砕波波高 $\mathrm{H}$ 。 はアイバーセンの波形勾配 $\mathrm{H}$ 。/Loとの関係図より求め、砕波の水平粒子速度 C は砕波点における波形が、そのまま構造物に作用するとして、孤立波理論による水粒子速度と同一とみなして 次式を用いた。

$$
C=\sqrt{g h_{b}\left(1+\frac{H_{b}}{h_{b}}\right)}
$$

また, 各水深の求める水粒子速度 $\mathrm{u}$ は、マックコーワンの波直下の水平速度分布図と、式（2．2）を用いて求 めた。そして各点における波力 $\mathrm{dF}$ (式2.1)を求めて総計し、作用棇波力 F 求め、抗力係数 $\mathrm{C}$ 。を算出した。 以上の結果を図-5に示す。

\section{3 実験考察}

抗力係数 $\mathrm{C}_{\mathrm{p}}$ は一般的にレイノルズ数の増大とともに減少し、質量係数 $\mathrm{C}$ м はレイノルズ数の変化に影響を受 けないと報告されている。本実験の海底勾配 0 の状態（非砕波）でのレイノルズ数 Reは $3 \times 10^{4}$ 程度であ る。本実験結果から抗力係数 $C_{\mathrm{D}}$ は図-4(1) に示されるように0．9〜1．5 を示し、質量係数 $\mathrm{C}_{\mathrm{M}}$ は図-4(2) に示されるように1．7〜2，1を示し、このことは一般的な值を示していると思われる。

次に海底勾配 1：30 (碎波) の場合、 $\mathrm{R}$ e は $1 \times 10^{5}$ 程度であり、図-5に示されるようにReに対し抗力 係数は大きく、1．0〜1．5の範囲となった。この原因として、波浪が構造物に衝突する時の跣波の作用によ ると一部考えられる。円柱に作用する跣波力は明らかにされていなが、設計時には考虑しなければならないし、 
抗力係数 $\mathrm{C}_{\mathrm{D}}$ 值についてはさらには生物付着による直径、表面粗度の増加の検討が必要である。

6. おわりに

今日の社会ニーズでは海洋レジャーへ の関心を抱いているのに、一部の人々は お金持ちのあぞひ、若者の道楽と従来の 考えをもっている。余睱を持ち、コスト が下がれば海洋レジャーを楽しみたいと 考えている潜在需要は各調査によって多 いことがわっかている。パインコーン型 ヨット保管構造物は従来の平面的なマリ 一ナでなく、立体的に効率よく海域を利 用し、より多くのヨットが収容できるの で管理コストも低くなり、なおかつマリ 一ナを中心に総合マリンリソートに成り 得る可能性を持っている。漁業、地域住 民と海洋性レクリエーションの関係は、 改善しつつあるものの決して良好なもの

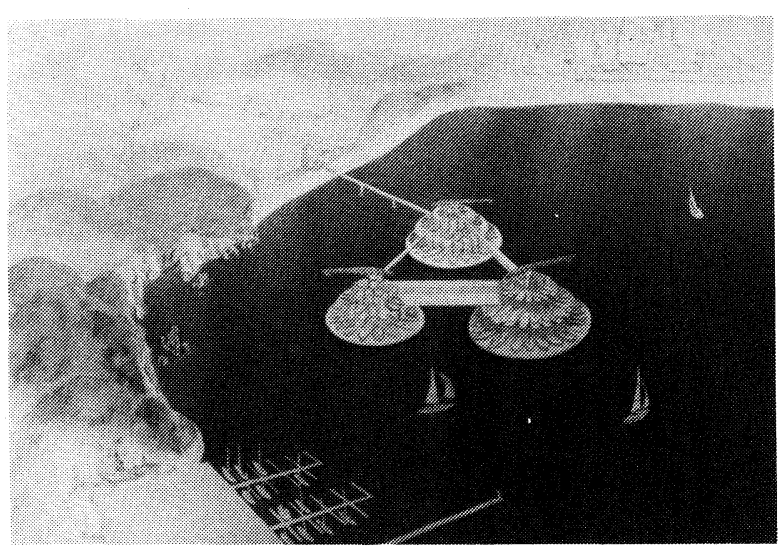

写真-1パインコーン型ヨット保管構造物の構想図

ではない。そのため海洋レクリエーションが発展するには、漁業協同組合との調整、漁業とマリンスポーッとの 結びつきを考慮して、漁業協同組合、地域関係者、民間を中心とした結合をはかり、文化的なまちづくりを行な わなければならない。また海洋性レクリエーション基地の建設には、きれいな海が必要である。そのために自然 景観を損なわない、また根本的な海洋污染防止の対策をよりいっそうしなければならない。これからの余暇の過 ごしかたは休暇の増加にともない長期滞在型にますますなると思われ、広域的、総合的観点からの立地選定と、 都市計画等との調整を十分配慮する必要がある。

今後の課題としてクレーン、またヨット保管載置段とうに対する風圧による影響を検討する一方、ヨットの吊 揚げ、吊降ろしを容易に行なうための手段の検討も必要である。

[参考文献]

1) 運輸省運輸政策海洋・海事課 ; 海洋性レクリエーションの現状と展望（マリンレジャー白書`88）, 財団法人日本海事広報協会発行, 1988年11月

2) 長崎作治 ; ヨットに関するオフショアマリーナと立体的保管（駐艇）施設に対する考察, M a r i n e , 刊海事通信社発行, pp. 85-95, 1988年11月

3） 日本テトラポッド マリンレクリエーション研究会；ザ・マリーナ＆ビーチ（マリン・レクリエーショ ン施設のデザイン)，的書房発行，1989年 3月

4) 角野 隆・関野高志・大松重雄; 海洋構造物に作用する波力の実海域実験, 第12回海洋開発シンポジウム 論文集, pp. 83-88, 1987年6月

5) 長崎作治 ; 海洋構造物の設計と施行, 森北出版発行, 1970年 4 月

6) MacCamy, R.C. and R.A.Fuchs: Wave Forces on Piles: A Diffraction Theory, Tech. Memo. No.69., B. E. B Corps of Eng., 1954.

7) Morison, J.R., J.W. Johnson and M.P. 0'Brien: Experimental Studies of Forse on Piles, Proc. 4th Conf. on Coastal Eng., 1953

8) Reid, R. 0. and C.L.Bretschneider: The Design Wave in Deep Water or Shallow Water, Storm-Tide, and Forces on Vertical Piling and Large Submerged 0bjects, Agricultural and Mechanical College of Texas, Dept. of 0ceanogrphy, Tech. Rept. on Contract N0 $y-27474$, DA-49-005-erg 18, and N 7 onr-48704, Feb. 1954 (Unpublished). 